\title{
Establishment and genetic characterization of a novel mixed-phenotype acute leukemia cell line with EP300-ZNF384 fusion
}

\author{
Nana Ping ${ }^{1,3+}$, Huiying Qiu ${ }^{1 \dagger}$, Qian Wang ${ }^{1 \dagger}$, Haiping Dai ${ }^{1}$, Changgeng Ruan ${ }^{1,3}$, Stefan Ehrentraut ${ }^{2}$, Hans G. Drexler ${ }^{2}$,
} Roderick A. F. MacLeod ${ }^{2}$ and Suning Chen ${ }^{1,3^{*}}$

\begin{abstract}
Herein, we describe the establishment and characterization of the first mixed-phenotype acute leukemia cell line $(\mathrm{JlH}-5)$. The $\mathrm{JlH}-5$ cell line was established from leukemia cells with B lymphoid/myeloid phenotype from a female mixed-phenotype acute leukemia patient. JIH-5 cells exhibit an immunophenotype comprised of myeloid and $B$ lymphoid antigens. Whole-exome sequencing revealed somatic mutations in nine genes in $\mathrm{JIH}-5$ cells. Transcriptional sequencing of $\mathrm{JH}-5$ cells identified EP300-ZNF384 fusion transcript, which is a recurrent alteration in B cell acute lymphoblastic leukemia. Our results suggest that the $\mathrm{JH}-5$ cell line may serve as a tool for the study of mixed-phenotype acute leukemia or EP300-ZNF384.
\end{abstract}

Keywords: Mixed-phenotype acute leukemia, Leukemia cell line, Next-generation sequencing, EP300-ZNF384

\section{Findings}

In a minority of patients with acute leukemia, it is difficult to determine the lineage origin because of the expression of both lymphoid and myeloid lineagespecific antigens [1-5]. The 2008 World Health Organization (WHO) classification introduced a new designation for this entity, mixed-phenotype acute leukemia (MPAL) [6]. Tumor cells are characterized by various biomarkers, such as cytogenetic, molecular genetic, or epigenetic aberrations [7-11]. However, the pathogenesis and optimal therapy of patients with MPAL remain largely undefined. Although several leukemia cell lines were once reported as BAL cell lines [12-17], none fulfill the WHO 2008 criteria for MPAL. So far, no cell line established from patients

\footnotetext{
* Correspondence: chensuning@suda.edu.cn

${ }^{\dagger}$ Equal contributors

'Jiangsu Institute of Hematology, Key Laboratory of Thrombosis and Hemostasis of Ministry of Health, The First Affiliated Hospital of Soochow University, Suzhou, People's Republic of China

${ }^{3}$ Collaborative Innovation Center of Hematology, Soochow University,

Suzhou, People's Republic of China

Full list of author information is available at the end of the article
}

with MPAL has been reported. Recently, we established the first human MPAL cell line, JIH-5. Herein, we present the phenotypic, genetic, and functional properties of JIH-5 cells. We applied next-generation sequencing (NGS) technology to unravel the transcriptome of $\mathrm{JIH}-5$ cells.

A 21-year-old female with MPAL was admitted to our hospital in December 2008. Bone marrow sample was obtained from the patient with informed consent in December 2009 during the second relapse. Mononuclear cells were cultured in Iscove's Modified Dulbecco's Medium with $20 \%$ fetal calf serum. The leukemia cells exhibited gradual cell proliferation 2 months after primary culture was initiated. The cell line was designated JIH-5. JIH-5 cells were tolerant to freezing in defined medium, storage in liquid nitrogen, thawing, and subsequent expansion. JIH-5 cells grow as single cells in suspension culture.

JIH-5 cells exhibit medium-sized spheroidal morphologies and large round nuclei with fine nuclear chromatin (Fig. 1a). The immunoprofiles of the JIH5 cells are summarized in Table 1 . JIH-5 cells express typical antigens of myeloid lineages (CD13, 

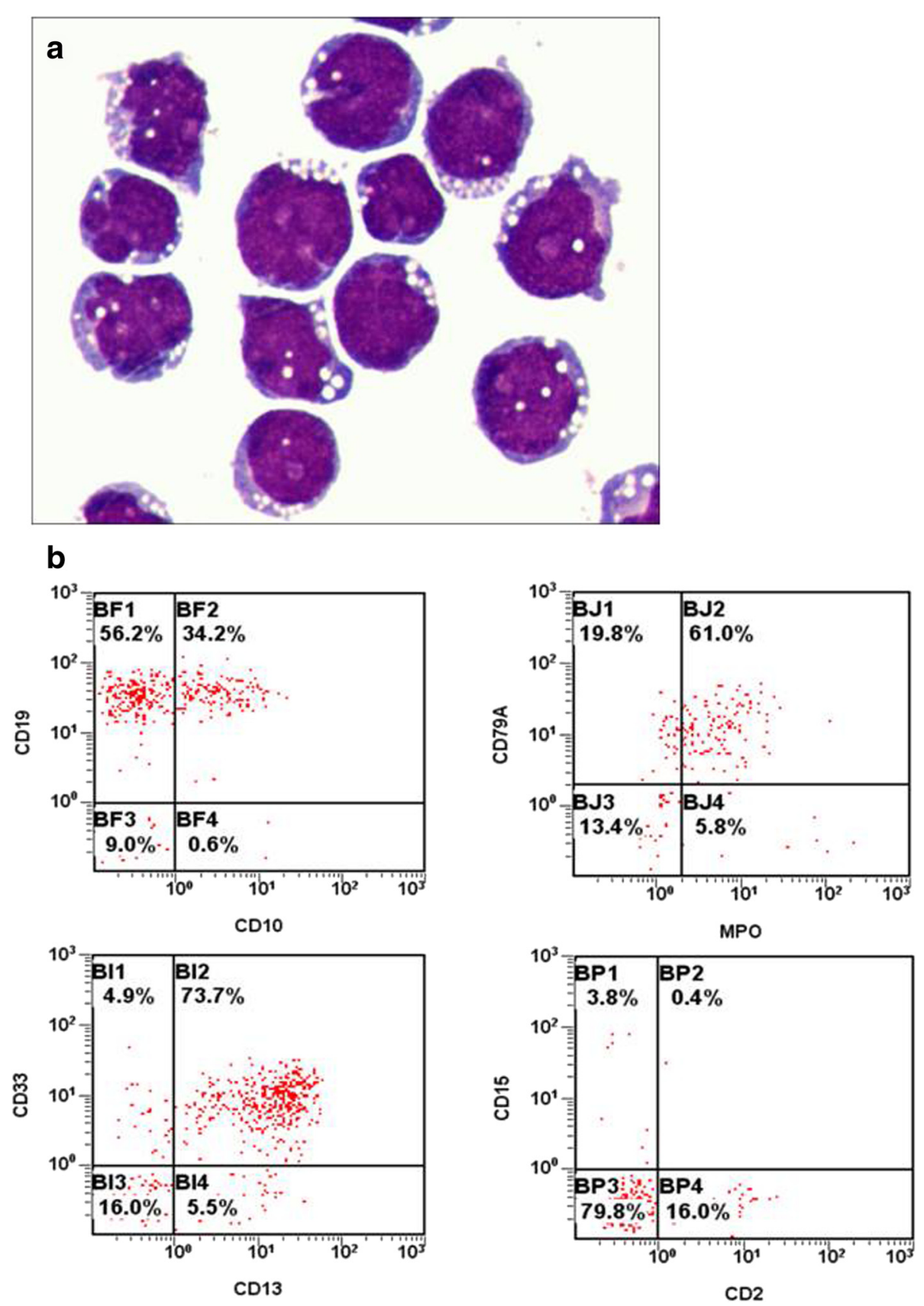

Fig. 1 Morphological and immunophenotypic analysis of JH-5. a. Morphology of SHI-1 cells on Wright's staining under a light microscopy (original magnification $\times 1000$ ). b. Immunophenotypic features of $\mathrm{JH}-5$ cells

CD15, CD33, and cMPO), as well as antigens of $\mathrm{B}$ lymphoid lineages (CD10, CD19, CD22, CD23, and cCD79a) (Fig. 1b). The negative polymerase chain reaction (PCR) results with EBV and mycoplasma specific primers excluded EBV and mycoplasma contamination. The colony formation rate of JIH-5 cells was $1.41 \%$ by semi-solid methylcellulose clonogenic assay. Tumor masses were found in one of six mice injected with JIH-5 cells after 83 days. The genetic identity of JIH-5 cells was compared to BM cell sample from the patient using short tandem repeat PCR. The results of authentication analysis indicated that the JIH-5 cells remained genetically identical to the founding tumor cells. 
Table 1 Immunophenotypic characterization of the $\mathrm{JH}-5$ cells and the primary leukemia cells

\begin{tabular}{|c|c|c|c|}
\hline \multirow{2}{*}{$\begin{array}{l}\text { Antigen } \\
\text { (CD) }\end{array}$} & \multicolumn{2}{|c|}{ Primary leukemia cells (\%) } & \multirow[t]{2}{*}{ JIH-5 cells (\%) } \\
\hline & At presentation & $\begin{array}{l}\text { At the second } \\
\text { relapse }\end{array}$ & \\
\hline
\end{tabular}

T/NK cell markers

$\begin{array}{ll}\text { CD2 } & 0.2 \\ \text { CD3 } & \text { ND } \\ \text { CD5 } & \text { ND } \\ \text { CD7 } & 0.3 \\ \text { CD56 } & \text { ND } \\ \text { CCD3 } & \text { ND }\end{array}$

$\begin{array}{ll}0.5 & 16.4 \\ \text { ND } & 1.1 \\ \text { ND } & 1.1 \\ 0.6 & 0 \\ \text { ND } & 1.4 \\ 0 & 0.3\end{array}$

B cell markers

$\begin{array}{ll}\text { CD10 } & 5.6 \\ \text { CD19 } & 99.8 \\ \text { CD20 } & 0.1 \\ \text { CD22 } & \text { ND } \\ \text { CD23 } & \text { ND } \\ \text { FMC-7 } & \text { ND } \\ \text { CCD79a } & 97.6\end{array}$

$\begin{array}{ll}11.6 & 34.8 \\ 93.9 & 90.4 \\ 0.5 & 1.7 \\ \text { ND } & 73.6 \\ \text { ND } & 53.3 \\ \text { ND } & 2.1 \\ 93.6 & 80.8\end{array}$

Myeloid markers

$\begin{array}{ll}\text { CD13 } & 28.9 \\ \text { CD14 } & 0.2 \\ \text { CD15 } & 14.1 \\ \text { CD33 } & 85.2 \\ \text { CD64 } & \text { ND } \\ \text { MPO } & 11.9\end{array}$

Progenitor markers

$\begin{array}{llll}\text { CD34 } & 92.5 & 95.3 & 13.6 \\ \text { CD38 } & \text { ND } & \text { ND } & 30 \\ \text { CD117 } & 0.1 & 0.8 & 3.6 \\ \text { HLA-DR } & 65.8 & 11.2 & 52.2\end{array}$

Adhesion markers

CD11b ND

ND

0.9

Erythroid markers

$\begin{array}{llll}\text { CD71 } & \text { ND } & \text { ND } & 5.3 \\ \text { GPA } & \text { ND } & \text { ND } & 1.3\end{array}$

Megakaryocytic markers

$\begin{array}{llll}\text { CD41 } & \text { ND } & \text { ND } & 47.2 \\ \text { CD61 } & \text { ND } & \text { ND } & 1.1\end{array}$

Plasma cell markers

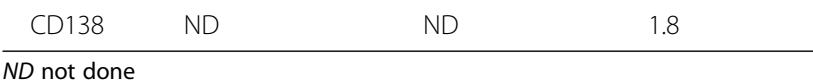

Combined G-banding and spectral karyotype (SKY) yielded the following karyotype for JIH-5: 46,XX,del(2) (q33)t(2;2) (p22;q37),t(4;5)(q35;q35),t(5;8)(q32;q22), der (6)del(6)(p21p22)t(6;10)(p23;q23),t(7;21)(p15;q21),der(9) $\operatorname{del}(9)(\mathrm{p} 21) \operatorname{del}(9)(\mathrm{q} 34.2), \operatorname{der}(10) \mathrm{t}(6 ; 10), \mathrm{t}(12 ; 22)(\mathrm{p} 13 ; \mathrm{q} 13)$, der(17)t(17;17)(p13;q22),del(19)(q13) (Fig. 2a, b). A total of ten copy number alterations (CNA) were detected by a$\mathrm{CGH}$. Both fluorescence in situ hybridization (FISH) and aCGH analysis showed a microdeletion affecting ETV6 gene (Fig. 2c, d). No mutations were detected in 15 acute leukemia-related genes by direct sequencing of PCR products in JIH-5 cells. The global expression profile of JIH-5 was compared to leukemic blast cells from the patient, and a range of cell lines representing $B$ and $T$ cell acute lymphoblastic leukemia (T-ALL). The results indicate that transcriptionally, JIH-5 cells more closely resemble cell lines of $B$ rather than T-ALL origin.

We captured and sequenced exomes from the paired sample of JIH-5 cells and control specimen in remission. We detected somatic tumor-specific mutations in a total of nine genes (eight missense and one nonsense mutations), including $\mathrm{ABCA} 8, \mathrm{BCHE}, \mathrm{CALCA}, \mathrm{CSTF} 2$, FPR1, KCNJ8, MAFB, STMN1, and TAAR8; all were heterozygous in JIH-5 cells. Bioinformatic evaluation of the transcriptional sequencing data and RT-PCR verification revealed six novel fusions, comprising three acting as translocations: EP300 (at 22q13) with both the adjacent ZNF384 and CHD4 (12p13), MSH2 (2p21) with NLK (17q11), and three microdeletions, HACL1COLQ (3p25), HDAC8-CITED1 (Xq13), and POLA2CDC42EP2 (11q13). Interestingly, the EP300 gene was found to fuse simultaneously with two partner genes located in 12p13, CHD4, and ZNF384 (Fig. 3a). Further FISH analysis with BAC and fosmid clones flanking EP300, CHD4, and ZNF384 confirmed breakpoints within CHD4 and EP300 due to a complex, apparently insertional, rearrangement involving $12 \mathrm{p} 13$ and $22 \mathrm{q} 13$ (Fig. 3b). Mutations of EP300 have been detected in Rubinstein-Taybi syndrome and some solid tumors [1822]. The EP300 was found to be fused with MLL in an AML patient harboring $\mathrm{t}(11 ; 22)(\mathrm{q} 23 ; \mathrm{q} 13)$ [23]. CHD4 encodes a catalytic subunit of the NuRD complex and plays an important role in transcriptional regulation, chromatin assembly, and DNA damage repair [24]. The ZNF384 gene has been observed recurrently fused with EWSR1, TAF15, or E2A in acute leukemia $[25,26]$. Recently, the EP300-ZNF384 was identified as a recurrent aberration in B cell acute lymphoblastic leukemia (BALL) [27]. The genetic abnormalities found in JIH-5 cells are detailed in Table 2.

In summary, we established a novel MPAL cell line, JIH-5, and characterized its biologic background comprehensively to show a novel oncogenomic gene fusion together with an associated cluster of mutations. Our findings suggested that the JIH-5 cell line may serve as a tool for the study of MPAL or EP300-ZNF384. 


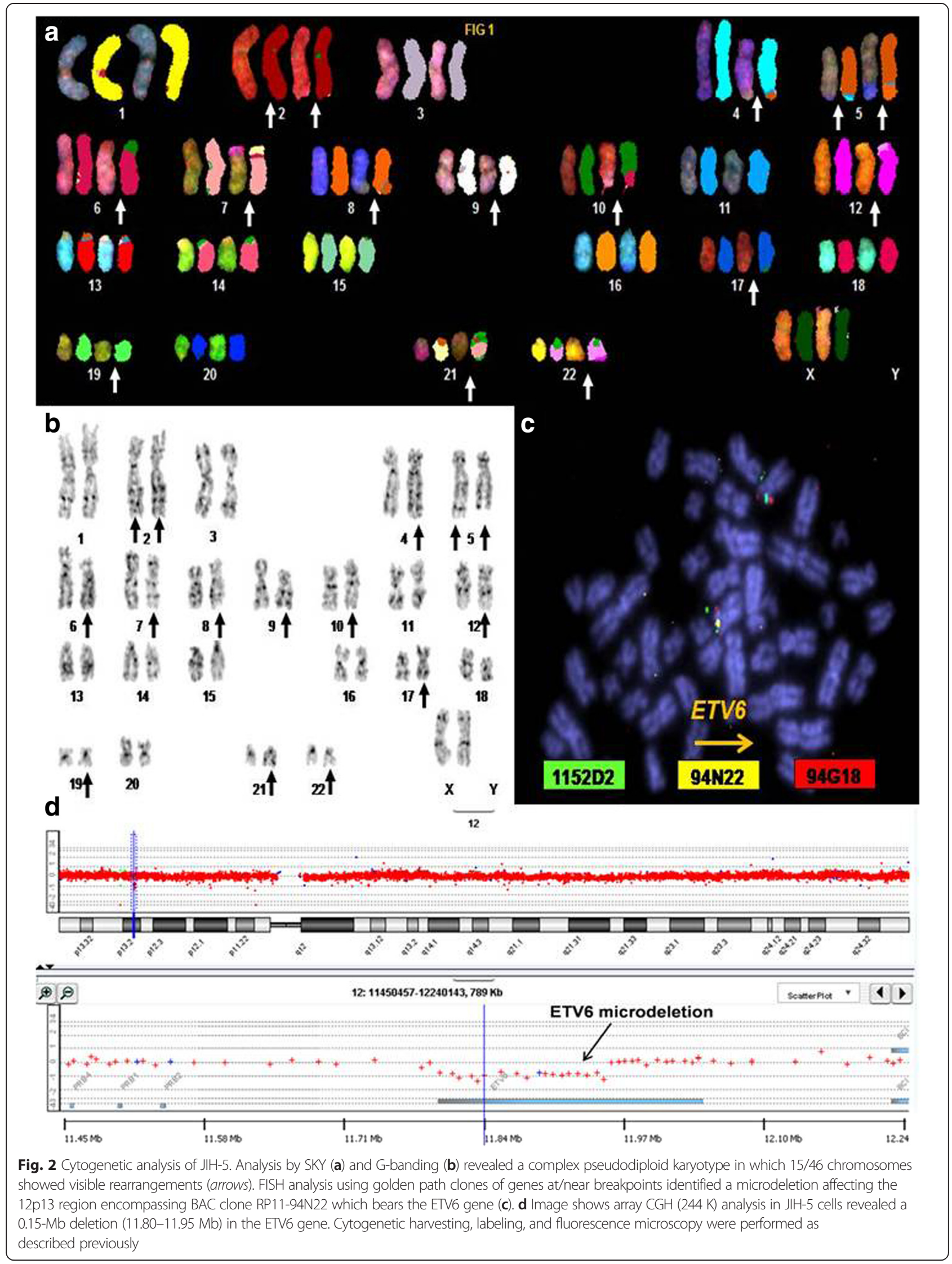




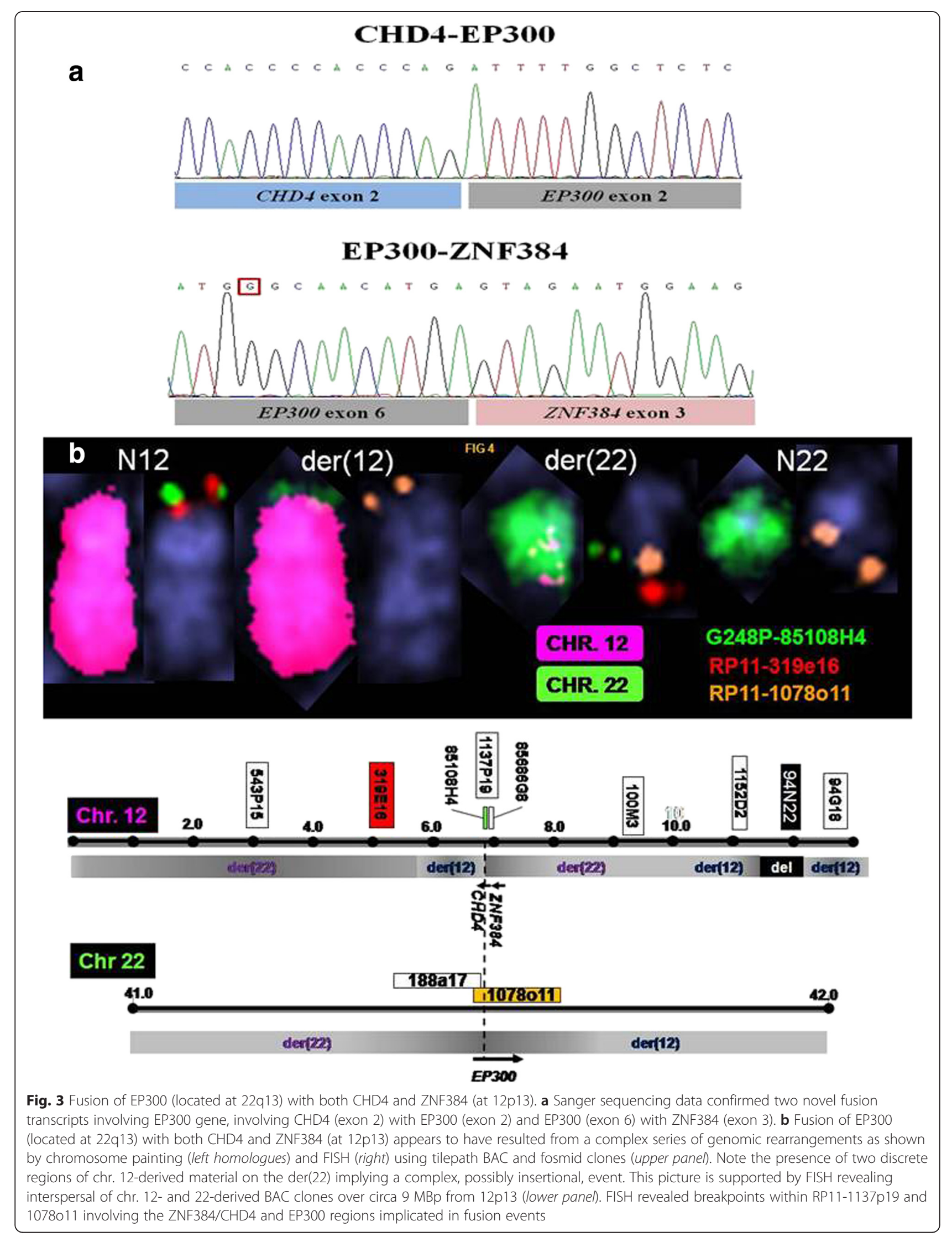


Table 2 Synopsis of data on the JIH-5 cell line

\begin{tabular}{ll}
\hline Parameter & JIH-5 \\
\hline Clinical data & \\
Patient & 21-year-old female \\
Diagnosis & MPAL \\
Treatment status & At the second relapse \\
$\begin{array}{l}\text { Specimen } \\
\text { Year of }\end{array}$ & BM \\
establishment & 2009 \\
$\begin{array}{l}\text { Culture } \\
\text { characterization }\end{array}$ & \\
Culture medium & IMDM $+20 \%$ FCS \\
Growth pattern & Single cells in suspension \\
$\begin{array}{l}\text { Doubling time } \\
\text { Optimal cell }\end{array}$ & $97 \mathrm{~h}$ \\
density & $1 \times 10^{6}$ cells/ml \\
Optimal split & $1: 3$ every 3-4 days \\
Cryopreservation & In 70\% medium, 20 \% FCS, 10\% DMSO \\
Morphology & medium-sized spheroidal morphologies \\
Viral status & Negative for EBV \\
Contamination & Negative for mycoplasma \\
Authentication & $\begin{array}{l}\text { Yes (by DNA finger printing, cytogenetic } \\
\text { characteristics, }\end{array}$ \\
immunoprofile)
\end{tabular}

Immunoprofiles

$\begin{array}{ll}\text { Myelocytic } & \text { CD13+, CD33+, CD15+, MPO+ } \\ \text { B lymphoid } & \text { CD10+, CD19+, CD22+, CD23+, cCD79a+ } \\ \text { Megakaryocytic } & \text { CD41+ } \\ \text { Progenitor } & \text { CD38+, HLA-DR+ } \\ \text { Plasma cell } & \text { CD138+ }\end{array}$

Genetic characterization

Karyotypic analysis $\quad 46, X X$,del(2)(q33)t(2;2)(p22;q37), t(4;5)(q35; q35), in conjunction with $t(5 ; 8)(q 32 ; q 22)$, der(6)del(6)(p21p22)t(6;10)(p23;q23), SKY

Array-CGH

Next-generation sequencing

Whole-exome sequencing

Transcriptome sequencing t(7;21)(p15;q21,der(9)del(9)p21)del(9)(q34.2), der(10) $\mathrm{t}(6 ; 10), t(12 ; 22)(\mathrm{p} 13 ; q 13), \operatorname{der}(17) t(17 ; 17)(\mathrm{p} 13 ; q 22)$, del(19)(q13)

del(2)(q33.1-q37.3), del(6)(p21.2-p21.31), del(8)(q21.2), del(8)(q23.3-q24.11), del(9)(q21.33-q34.12), del(10)(q23.33-q24.1), del(10)(q25.1), del(12)(p13.2), del(19)(q13.32), amp(17)(q21.32-q25.3)

Somatic mutations in ABCA8, BCHE, CALCA, CSTF2, FPR1, KCNJ8, MAFB, STMN1, TAAR8

EP300-ZNF384, CHD4-EP300, MSH2-NLK, HACL1-COLQ, HDAC8-CITED1, POLA2-CDC42EP2

\section{Abbreviations}

B-ALL: B cell acute lymphoblastic leukemia; CNA: copy number alterations; EBV: Epstein-Barr virus; FCM: flow cytometry; FISH: fluorescence in situ hybridization; MOAP: mitoxantrone, cytosine arabinoside, vindesine, and dexamethasone; MPAL: mixed-phenotype acute leukemia; NGS: nextgeneration sequencing; NuRD: nucleosome remodeling and deacetylase;
PCR: polymerase chain reaction; SKY: spectral karyotype; T-ALL: T cell acute lymphoblastic leukemia.

\section{Competing interests}

The authors declare that they have no competing interests.

\section{Authors' contributions}

SC was the principal investigator. NP, HQ, and QW performed most of the experiments. $\mathrm{SE}, \mathrm{CR}$, and RM performed the cytogenetic and gene expression array analysis. SC, HD, and RM wrote the manuscript. All authors read and approved the final manuscript.

\section{Acknowledgments}

This work was supported by grants from the National Key Scientific Projects of China (2011CB933501), the Priority Academic Program Development of Jiangsu Higher Education Institutions, the Natural Science Foundation of China $(81070416,81270617)$, the Jiangsu Provincial Special Program of Medical Science (BL2012005), the Jiangsu Province's Key Medical Center (ZX201102), the National Public Health Grand Research Foundation (No.201202017), and the Jiangsu Province Natural Science Fund for Distinguished Young Scholars (BK2012006).

\section{Author details}

${ }^{1}$ Jiangsu Institute of Hematology, Key Laboratory of Thrombosis and Hemostasis of Ministry of Health, The First Affiliated Hospital of Soochow University, Suzhou, People's Republic of China. ${ }^{2}$ DSMZ - German Collection of Microorganisms and Cell Cultures, Braunschweig, Germany. ${ }^{3}$ Collaborative Innovation Center of Hematology, Soochow University, Suzhou, People's Republic of China.

\section{Received: 15 July 2015 Accepted: 11 August 2015}

Published online: 21 August 2015

\section{References}

1. Mirro J, Zipf TF, Pui $C H$, Kitchingman G, Williams D, Melvin S, et al. Acute mixed lineage leukemia: clinicopathologic correlations and prognostic significance. Blood. 1985;66(5):1115-23.

2. Ruiz-Argüelles GJ, Lobato-Mendizábal E, Marín-López A. The incidence of hybrid acute leukaemias. Leuk Res. 1988;12(9):707-9.

3. Weir EG, Ali Ansari-Lari M, Batista DA, Griffin CA, Fuller S, Smith BD, et al. Acute bilineal leukemia: a rare disease with poor outcome. Leukemia. 2007:21(11):2264-70.

4. Wolach O, Stone RM. How I treat mixed-phenotype acute leukemia. Blood. 2015;125(16):2477-85.

5. Weinberg OK, Arber DA. Mixed-phenotype acute leukemia: historical overview and a new definition. Leukemia. 2010;24(11):1844-51.

6. Borowitz MJ, Bene MC, Harris NL, Porwit A, Matutes E. Acute leukemias of ambiguous lineage. In: Swerdlow SH et al., editors. WHO Classification of Tumours of Haematopoietic and Lymphoid Tissues. Lyon: IARC Press; 2008. p. $150-5$.

7. Li B, Gale RP, Xiao Z. Molecular genetics of chronic neutrophilic leukemia, chronic myelomonocytic leukemia and atypical chronic myeloid leukemia. J Hematol Oncol. 2014;7:93.

8. Smith AD, Roda D, Yap TA. Strategies for modern biomarker and drug development in oncology. J Hematol Oncol. 2014;7:70.

9. Gutierrez SE, Romero-Oliva FA. Epigenetic changes: a common theme in acute myelogenous leukemogenesis. J Hematol Oncol. 2013;6:57.

10. Sweet K, Zhang L, Pinilla-lbarz J. Biomarkers for determining the prognosis in chronic myelogenous leukemia. J Hematol Oncol. 2013;6:54.

11. Zhao Y, Huang H, Wei G. Novel agents and biomarkers for acute lymphoid leukemia. J Hematol Oncol. 2013;6:40.

12. Suzuki S, Uozumi K, Hanada S, Lin XY, Ohno N, Takatsuka Y, et al. A novel c-kit positive biphenotypic acute leukemia cell line, TMBL-1, carnying a p53 point mutation. Leuk Lymphoma. 2003;44(5):849-57.

13. Matsuo Y, Drexler HG, Takeuchi M, Orita K. A novel biphenotypic B-cell precursor leukemia cell line (NALM-29) carrying t(9;22)(q34;q11) established from a patient with acute leukemia. Leuk Res. 1999;23(8):731-40.

14. Inokuchi $\mathrm{K}$, Shinohara T, Futaki M, Hanawa H, Tanosaki S, Yamaguchi H, et al. Establishment of a cell line with variant BCR/ABL breakpoint expressing P180BCR/ABL from late-appearing Philadelphia-positive acute biphenotypic leukemia. Genes Chromosomes Cancer. 1998;23(3):227-38. 
15. Ariyasu T, Matsuo Y, Harashima A, Nakamura S, Takaba S, Tsubota T, et al Establishment and characterization of "biphenotypic" acute leukemia cell lines with a variant Ph translocation $\mathrm{t}(9 ; 22 ; 10)(\mathrm{q} 34 ; \mathrm{q} 11 ; \mathrm{q} 22)$. Hum Cell. 1998;11(1):43-50.

16. Greil J, Gramatzki M, Burger R, Marschalek R, Peltner M, Trautmann U, et al. The acute lymphoblastic leukaemia cell line SEM with $t(4 ; 11)$ chromosomal rearrangement is biphenotypic and responsive to interleukin-7. Br J Haematol. 1994;86(2):275-83.

17. Tanabe S, Fukuhara S, Yoneda T, Ohmori K, Nosaka T, Hatanaka M, et al. Characterization of a novel biphenotypic leukemia cell line, TA-1, with myeloperoxidase and inducible cytoplasmic mu chain: altered rearrangement patterns of antigen receptor genes. Int J Hematol. 1993;57(3):229-43.

18. Zimmermann N, Acosta AM, Kohlhase J, Bartsch O. Confirmation of EP300 gene mutations as a rare cause of Rubinstein-Taybi syndrome. Eur J Hum Genet. 2007;15(8):837-42.

19. Gayther SA, Batley SJ, Linger L, Bannister A, Thorpe K, Chin SF, et al. Mutations truncating the EP300 acetylase in human cancers. Nat Genet. 2000;24(3):300-3.

20. Bryan EJ, Jokubaitis VJ, Chamberlain NL, Baxter SW, Dawson E, Choong DY, et al. Mutation analysis of EP300 in colon, breast and ovarian carcinomas. Int J Cancer. 2002;102(2):137-41.

21. Koshiishi N, Chong JM, Fukasawa T, Ikeno R, Hayashi Y, Funata N, et al. p300 gene alterations in intestinal and diffuse types of gastric carcinoma. Gastric Cancer. 2004;7(2):85-90.

22. Kim MS, Lee $\mathrm{SH}$, Yoo NJ, Lee $\mathrm{SH}$. Frameshift mutations of tumor suppressor gene EP300 in gastric and colorectal cancers with high microsatellite instability. Hum Pathol. 2013:44(10):2064-70.

23. Ida K, Kitabayashi I, Taki T, Taniwaki M, Noro K, Yamamoto M, et al. Adenoviral E1A-associated protein p300 is involved in acute myeloid leukemia with $t(11 ; 22)(q 23 ; q 13)$. Blood. 1997;90(12):4699-704.

24. Musselman CA, Ramírez J, Sims JK, Mansfield RE, Oliver SS, Denu JM, et al. Bivalent recognition of nucleosomes by the tandem PHD fingers of the CHD4 ATPase is required for CHD4-mediated repression. Proc Natl Acad Sci U S A. 2012;109(3):787-92.

25. Zhong CH, Prima V, Liang X, Frye C, McGavran L, Meltesen L, et al. E2A-ZNF384 and NOL1-E2A fusion created by a cryptic t(12;19)(p13.3; p13.3) in acute leukemia. Leukemia. 2008;22(4):723-9.

26. Martini A, La Starza R, Janssen H, Bilhou-Nabera C, Corveleyn A, Somers R, et al. Recurrent rearrangement of the Ewing's sarcoma gene, EWSR1, or its homologue, TAF15, with the transcription factor CIZ/NMP4 in acute leukemia. Cancer Res. 2002;62(19):5408-12.

27. Gocho Y, Kiyokawa N, Ichikawa H, Nakabayashi K, Osumi T, Ishibashi T et al A novel recurrent EP300-ZNF384 gene fusion in B-cell precursor acute lymphoblastic leukemia. Leukemia. 2015 May 6. doi: 10.1038/leu.2015.111. [Epub ahead of print]

\section{Submit your next manuscript to BioMed Central and take full advantage of:}

- Convenient online submission

- Thorough peer review

- No space constraints or color figure charges

- Immediate publication on acceptance

- Inclusion in PubMed, CAS, Scopus and Google Scholar

- Research which is freely available for redistribution 